\title{
The Chemical Compositions of Thermal Waters at Ciarinem and Cilayu, Pameungpeuk, West Java - Indonesia
}

\author{
N.R. Herdianita ${ }^{1, *}$ \& B. Priadi ${ }^{2}$ \\ ${ }^{1}$ Research Group on Applied Geology, Faculty of Earth Science and Mineral \\ Technology - FIKTM, Institute of Technology Bandung (ITB) \\ Jalan Ganesa 10 Bandung 40125 - Indonesia \\ Phone/Fax : 62-22-2502197, Email: herdianita@gc.itb.ac.id \\ ${ }^{2}$ Research Group on Geology and Paleontology, Faculty of Earth Science and Mineral \\ Technology - FIKTM, Institute of Technology Bandung (ITB) \\ Jalan Ganesa 10 Bandung 40125 - Indonesia, Phone/Fax: 62-22-2502197, Email: \\ bpriadi@gc.itb.ac.id
}

\begin{abstract}
Thermal waters at Ciarinem and Cilayu, Pameungpeuk, West Java, Indonesia have different characteristics: Ciarinem water is a steam heated sulfate type and occurs as hot springs, whereas Cilayu water discharges as hot pools and is a chloride water type. Their chemical compositions indicate that the thermal waters are outflows of a volcanic-magmatic associated geothermal system. The solute geothermometers calculate that the subsurface reservoir temperatures range from $150^{\circ}$ to $200^{\circ} \mathrm{C}$.
\end{abstract}

Keywords: high temperature; liquid dominated geothermal system; surface manifestation; volcanic associated.

\section{Introduction}

Ciarinem thermal waters are located near Ciarinem River, Gunung Angsana, and Cilayu thermal waters are close to Cilayu River, Gunung Kendang. The coordinates of these surface expressions are given in Table 1 . The thermal waters of Ciarinem and Cilayu are about $70 \mathrm{~km} \mathrm{S-SE} \mathrm{of} \mathrm{Bandung} \mathrm{or} 55 \mathrm{~km} \mathrm{SW}$ of Garut; the closest town is Pameungpeuk in the south coast of West Java, Indonesia (Figure 1).

* Corresponding Author

Received April, 2006, Revised September, $8^{\text {th }}$, 2006, Accepted for publication September, $8^{\text {th }}$, 2006. 


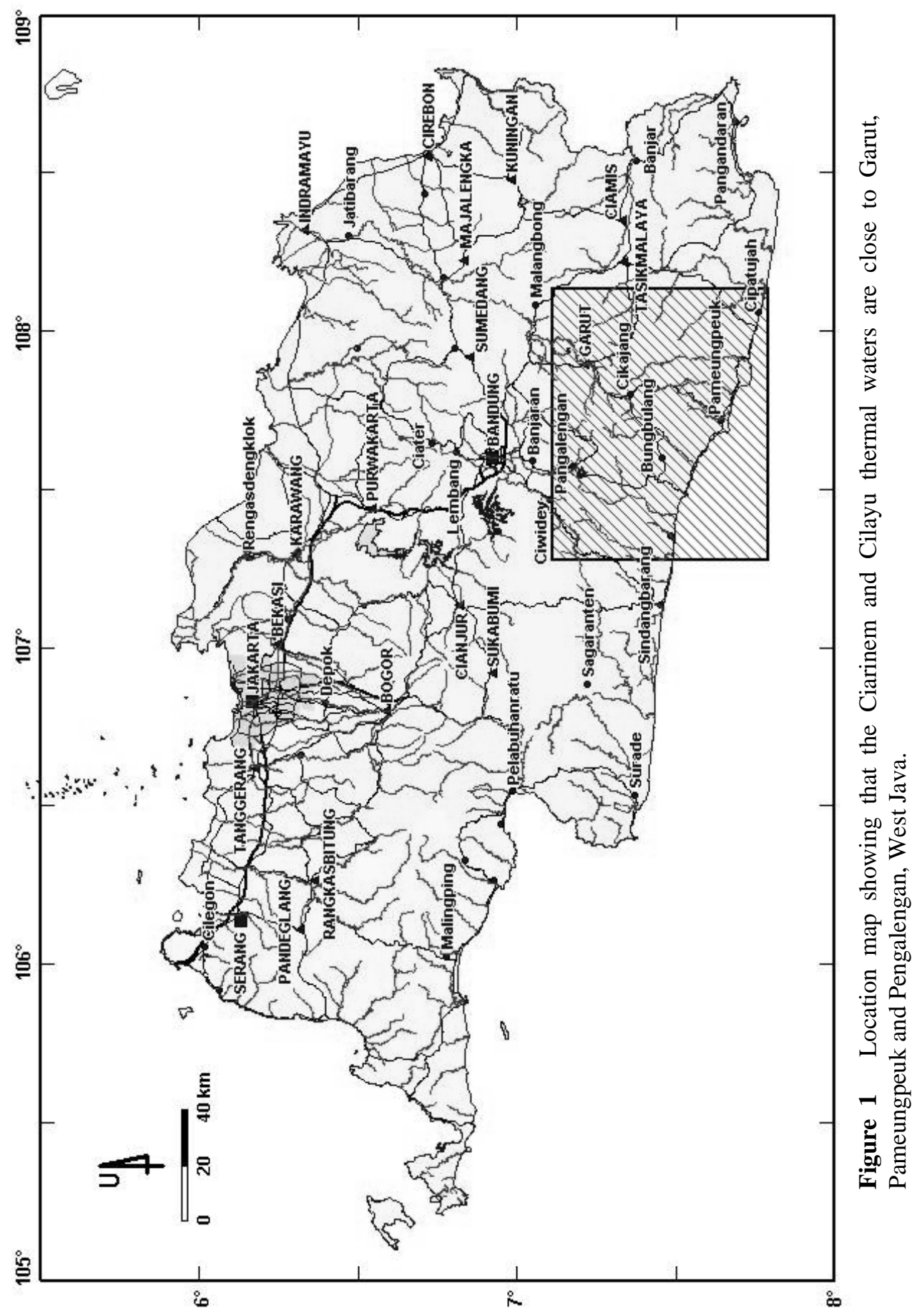




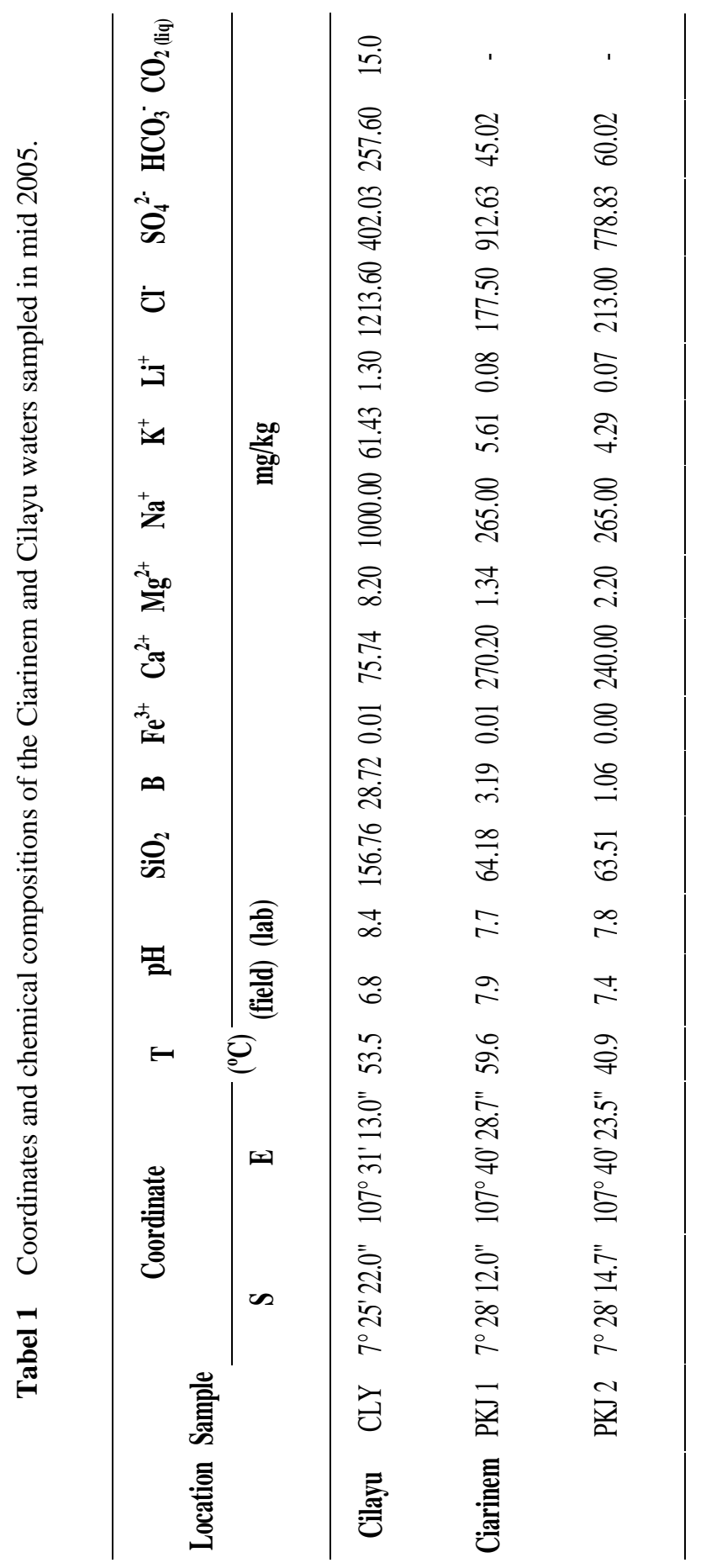


The surface manifestations of Ciarinem and Cilayu are a part of 6,101 MWe geothermal potential of West Java [1] and have been mapped by [2]. However, prior to this research, the characteristics of the thermal waters were not known. This paper describes the characteristics of Ciarinem and Cilayu thermal waters, including their appearances and origins in a geothermal system based on their chemistry of fluids.

\section{Ciarinem Thermal Water}

\section{$2.1 \quad$ Setting}

The surface manifestation at Ciarinem lies in the physiographic zone of southern mountain, i.e. at the Pengalengan section [3]. It is located at the NW flank of Gunung Angsana and south of Ciarinem River, surrounded by several extinct volcanoes. The lithology of the area is dominated by undifferentiated Pliocene and Plio-Pleistocene volcanic rocks that consist of tuff, tuff breccia, andesite breccia, breccia and andesite lavas, associated with pyroxene and hornblende andesite [2]. The geological structure includes a NE-SW strike slip fault cutting from the Papandayan volcano to the south coast and an E-W normal fault [2]. These faults were likely generated by the compression from the south to north during the late Oligocene and early Miocene.

The geothermal surface expression of Ciarinem comprises three hot springs, which occur at Sukamulya Village, near Gunung Angsana, Pameungpeuk. The hot springs are called Pakenjeng (PKJ) 1, 2 and 3; PKJ 1 and 2 have been utilized directly as public hot pools. The PKJ 1 hot spring discharges at a contact between tuff breccia and lava of the undifferentiated old volcanic rocks. It has a flow of about $20 \mathrm{l} / \mathrm{min}$. The water is clear and has a temperature of $59.6^{\circ} \mathrm{C}$ and a pH between 7.8 and 8.0. There is no surface rock alteration, but there are thin, yellowish green layers of organic materials or of algal origin covering some rocks near the spring. The PKJ 2 hot spring discharges about 10 $\mathrm{m}$ away from PKJ 1. Similarly, the water is clear and odorless, but it has a lower temperature than PKJ 1, i.e. $40.9^{\circ} \mathrm{C}$. It has a $\mathrm{pH}$ of 7.4 and discharges at 20 $\mathrm{l} / \mathrm{min}$. PKJ 3 is located about $5 \mathrm{~m}$ from PKJ 1. The temperature and flow of PKJ 3 water are lower than PKJ 1; the water is $40.9^{\circ} \mathrm{C}$ and flows at $2 \mathrm{l} / \mathrm{min}$. The PKJ 3 hot spring discharges at andesite breccia. There is no rock alteration at the surface. The springs of PKJ 1 and PKJ 2 were sampled and analyzed.

\subsection{Spring Composition}

The chemical compositions of PKJ 1 and PKJ 2 waters are given in Table 1, showing that they are not significantly different. Figure 2 shows that PKJ 1 and PKJ 2 waters are classified as immature sulfate $\left(\mathrm{SO}_{4}\right)$ thermal waters. Sulfate 
water occurs commonly in volcanic geothermal areas, where steam condenses into surface waters. It forms in the shallowest parts of the system. The sulfate content is derived from oxidation of hydrogen sulfide $\left(\mathrm{H}_{2} \mathrm{~S}\right)$ to form $\mathrm{H}_{2} \mathrm{SO}_{4}$ in the oxidation zone, i.e. above the water table. However, unlike other sulfate waters in geothermal systems, the sulfate waters of PKJ 1 and PKJ 2 hot springs are of neutral $\mathrm{pH}$ ( $\mathrm{pH}=7$ to 8). Consequently, no dissolution of rock occurs. This could be due to shallow neutralization of the fluids that interact with the surrounding rocks.

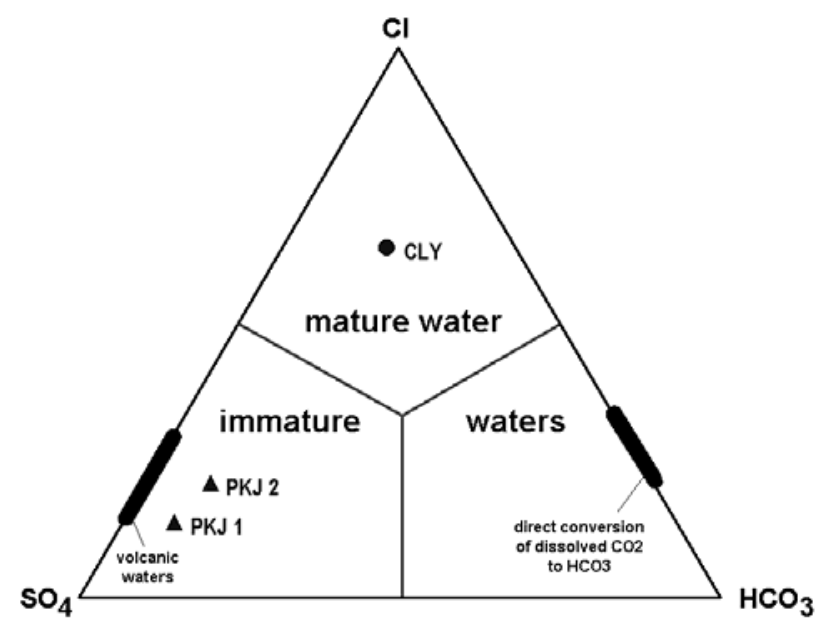

Figure 2 Relative concentrations of $\mathrm{Cl}, \mathrm{SO}_{4}$ and $\mathrm{HCO}_{3}$ of Ciarinem and Cilayu hot spring waters; letter symbols correspond to the springs listed in Table 1.

Figure 3 shows the relative concentrations of the conservative aqueous components $\mathrm{Cl}, \mathrm{Li}$ and $\mathrm{B}$ of PKJ 1 and $\mathrm{PKJ} 2$ thermal waters. The ratio of $\mathrm{B} / \mathrm{Cl}$ ranges from 0.01 to 0.02 , the ratio of $\mathrm{Li} / \mathrm{Cl}$ is about 0.0005 and the ratio of $\mathrm{Li} / \mathrm{B}$ is about 0.01 . The concentration of $\mathrm{Cl}$ of PKJ 2 water is higher than that of PKJ 1. This may cause PKJ 2 thermal water to be more equilibrated with surrounding rocks compared to the PKJ 1 water. Figure 4 shows that the thermal water of PKJ 2 is in partial equilibration, whereas the PKJ 1 water is immature water. However, it seems that the compositions of PKJ 1 and PKJ 2 thermal waters are affected by a mixture of waters that are relatively rich in $\mathrm{Mg}$ and that are of likely shallow origin. 


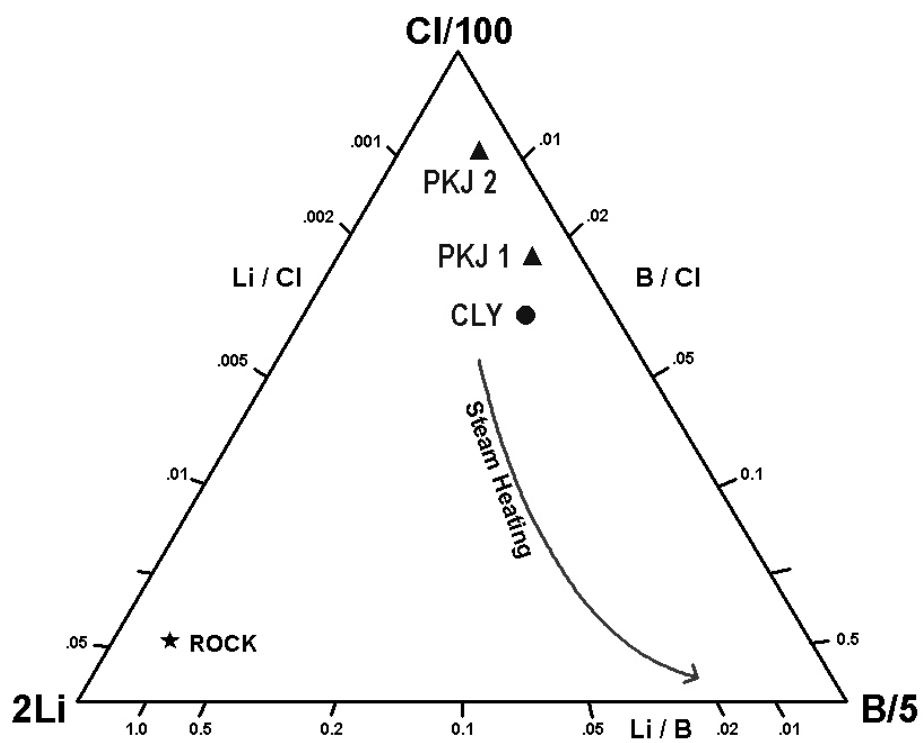

Figure 3 Relative concentrations of $\mathrm{Cl}, \mathrm{Li}$ and $\mathrm{B}$ of Ciarinem (PKJ 1 and PKJ 2) and Cilayu (CLY) thermal waters.

\section{$2.3 \quad$ Geothermometer}

Figure 4 also indicates that PKJ 1 and PKJ 2 waters are in equilibration temperatures in the range of 110 to $150^{\circ} \mathrm{C}$. Aqueous silica contents are evaluated in Figure 5 in relation to $\mathrm{K} / \mathrm{Mg}$ ratio. Figure 5 is similar to Figure 4 in that it allows simultaneous evaluation of two independent geothermometers. However, in contrast to the $\mathrm{K}-\mathrm{Na}$ geothermometer, both the quartz and the $\mathrm{K}$ $\mathrm{Mg}$ geothermometer tend to respond more quickly to sharp cooling gradients and subsequent re-equilibration [4]. The Ciarinem data indicate equilibrium temperatures of about $100^{\circ} \mathrm{C}$ only. 


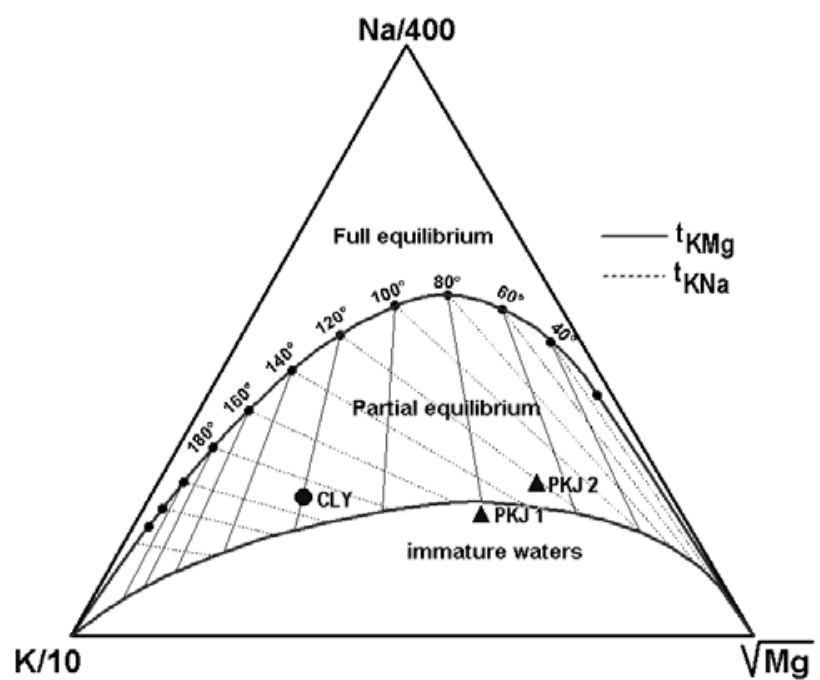

Figure 4 Relative concentrations of $\mathrm{Na}, \mathrm{K}$ and $\mathrm{Mg}$ of Ciarinem (PKJ 1 and PKJ 2) and Cilayu (CLY) thermal waters and simultaneous comparison of $T_{K N a}$ and $\mathrm{T}_{\mathrm{KMg}}$ geothermometers [5].

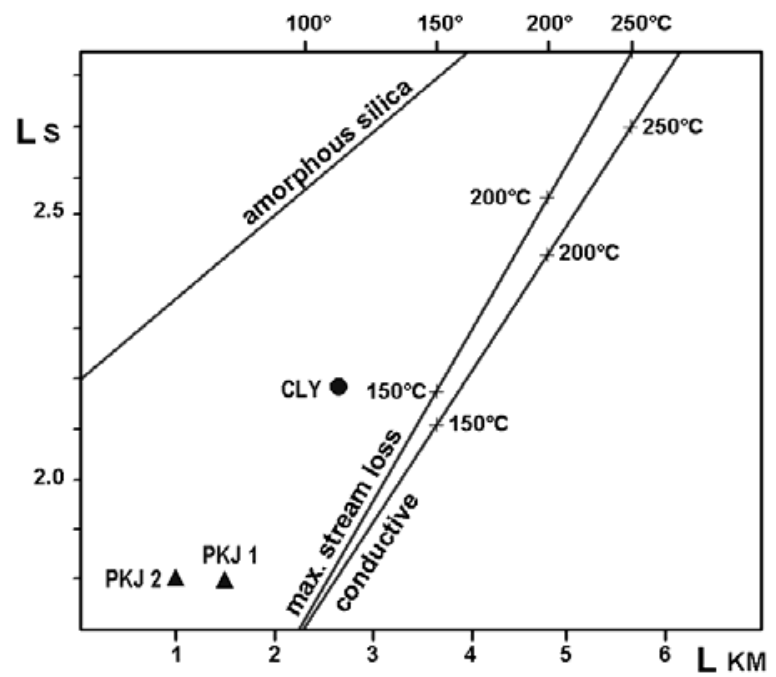

Figure 5 Log silica concentrations $\left(\mathrm{L}_{\mathrm{S}}\right)$ versus $\log \mathrm{c}^{2}{ }_{\mathrm{K}} / \mathrm{c}_{\mathrm{Mg}}\left(\mathrm{L}_{\mathrm{KM}}\right)$ of Ciarinem (PKJ 1 and PKJ 2) and Cilayu (CLY) hot spring waters, allowing simultaneous comparison of the silica and K-Mg geothermometers. The amorphous silica, the quartz maximum steam loss and the quartz conductive cooling lines are from [6]. 


\section{$3 \quad$ Cilayu Thermal Water}

\subsection{Setting}

Similar to the Ciarinem site, the Cilayu surface manifestation lies in the Pengalengan section of the physiographic zone of southern mountain [3]. It is located at the alluvial plain of the Cilayu River surrounded by several extinct volcanoes. The lithology of the area includes the Bentang and Kolederes Formations of Late Miocene to Plio-Pleistocene, Pleistocene tuffaceous breccia, and undifferentiated Plio-Pleistocene volcanic rocks [2, 7]. The geological structure is dominated by anticline and a NE-SW strike slip fault, as a result of the compression from south to north during the late Oligocene and early Miocene [2]. [7] also mentioned the occurrence of NW-SE faults.

The surface manifestation at Cilayu comprises three hot pools, which occur in the alluvial plain of the Cilayu River. The springs are not currently utilized, but flow freely to the river. Only one of the hot pools is described below, namely the Cilayu (CLY) hot spring; it is the hottest of the three, with a temperature of $53.5^{\circ} \mathrm{C}$. The water in the hot pool has a sulfuric smell, gas bubbles, and a field measurement $\mathrm{pH}$ of 6.8. In some places, the water surface is covered by a yellow to green colloid consisting of silica and algae. There is no surface alteration around the pools, but the weathering is intense.

\subsection{Spring Composition}

The chemical composition of CLY thermal water is given in Table 1 . The relative concentrations of $\mathrm{Cl}, \mathrm{SO}_{4}$ and $\mathrm{HCO}_{3}$ indicate that the water is a chloride (Cl) type, as shown in Figure 2. The occurrence of chloride water is very common in geothermal systems and it always relates to deep reservoir fluids. The chloride water of CLY hot spring contains $156.8 \mathrm{mg} / \mathrm{S} \mathrm{SiO}_{2}$. However, the fluid is under saturated with amorphous silica, hence there is no amorphous silica sinter around the mouth of the spring. The occurrence of colloid silica in association with organic matter or algae on the surface of the hot pool indicates a slow cooling of CLY thermal water by evaporation. The thermal water of $\mathrm{CLY}$ also contains $15 \mathrm{mg} / \mathrm{l}$ dissolved $\mathrm{CO}_{2}$ as $\mathrm{CO}_{3}{ }^{2-}$.

The field measurement shows that CLY water has a neutral $\mathrm{pH}(\mathrm{pH}=6.8)$. However, the $\mathrm{pH}$ is higher and slightly basic $(\mathrm{pH}=8.4)$ at room temperature $\left(25^{\circ} \mathrm{C}\right)$. The changes in $\mathrm{pH}$ with respect to the changes in fluid temperatures may be due to shallow neutralization by dissolved $\mathrm{CO}_{2}\left(\right.$ as $\mathrm{CO}_{3}{ }^{2-}$ ) in the reservoir fluids containing high chloride [8]. Another explanation is that the occurrence of $\mathrm{H}_{2} \mathrm{~S}$ can affect the change in the $\mathrm{pH}$ of fluids; in the field, $\mathrm{H}_{2} \mathrm{~S}$ will oxidize with the atmosphere on the surface of the hot pool, forming $\mathrm{H}_{2} \mathrm{SO}_{4}$ (to more than $400 \mathrm{mg} / \mathrm{l} \mathrm{SO}_{4}$ ). 
Figure 3 shows that the relative concentrations of $\mathrm{Cl}, \mathrm{Li}$ and $\mathrm{B}$ in the CLY thermal water are similar to that of PKJ 1 and PKJ 2 waters, i.e. plots near the chloride apex. The ratio of $\mathrm{B} / \mathrm{Cl}$ of CLY thermal water is about 0.03 and the ratios of $\mathrm{Li} / \mathrm{Cl}$ and $\mathrm{Li} / \mathrm{B}$ are 0.001 and 0.04 , respectively. The relative concentrations of $\mathrm{Na}, \mathrm{K}$ and $\mathrm{Mg}$ in Figure 4 show that the thermal water of CLY equilibrates partially with surrounding rocks.

\subsection{Geothermometer}

As shown in Figure 4, the chemical composition of CLY thermal water indicates reservoir temperatures of $180^{\circ}-200^{\circ} \mathrm{C}$. However, based on the geothermometers of quartz maximum steam loss and $\mathrm{K}-\mathrm{Mg}$, the reservoir fluid generating the CLY thermal spring has temperatures of about $150^{\circ} \mathrm{C}$ and $120^{\circ} \mathrm{C}$, respectively (Figures 4 and 5).

\section{$4 \quad$ Discussion}

The geothermal surface manifestations of Cilayu, Gunung Kendang and Ciarinem, Gunung Angsana are located in NW Pameungpeuk, West Java, within an 18-km distance. However, the thermal waters have different characteristics. The surface manifestation at Cilayu, Gunung Kendang comprises hot pools located in an alluvial plain, whereas that at Ciarinem, Gunung Angsana consists of hot springs occurring at the lithologic contact of lava and breccia at the flank of Gunung Angsana, south of Ciarinem River.

The relative concentrations of $\mathrm{Cl}, \mathrm{SO}_{4}$ and $\mathrm{HCO}_{3}$ can be used to understand surface and near surface conditions of geothermal systems. Figure 2 shows that the thermal waters of Cilayu are a chloride type and are of deep reservoir origin. Also note that in Cilayu there has been some mixing of the $\mathrm{SO}_{4}$ water through oxidation of dissolved $\mathrm{H}_{2} \mathrm{~S}$. It is the dissolved $\mathrm{H}_{2} \mathrm{~S}$ that causes the sulfuric smell in the Cilayu hot pool. Boron content is relatively high (Figure 3) due to the interaction between thermal waters and sedimentary rocks, i.e. from the Bentang or Kolederes Formations, or from alluvial deposits, which are predominant in the Cilayu area.

The thermal water of Cilayu has equilibrated with the surrounding rocks. Even though it is located in an alluvial plain, there is no mixing with $\mathrm{Mg}$ rich groundwater or surface water, as indicated by the relative concentrations of $\mathrm{Na}$, $\mathrm{K}$ and $\mathrm{Mg}$ (Figure 4). In contrast, the thermal water of Ciarinem contains relatively high $\mathrm{Mg}$, indicating a mixing with groundwater, possibly steam heated waters. This causes the thermal waters of Ciarinem to be immature $\mathrm{SO}_{4}$ water. 
If the relative concentrations of $\mathrm{Cl}, \mathrm{SO}_{4}$ and $\mathrm{HCO}_{3}$ can be used to interpret near surface conditions and processes affecting thermal fluids above a 1-km depth, the relative concentrations of $\mathrm{Cl}, \mathrm{Li}$ and $\mathrm{B}$ can indicate subsurface conditions of up to $5 \mathrm{~km}$ and can permit the assessment of deep thermal inputs [4]. Figure 3 shows that the results from Cilayu and Ciarinem are clustered, suggesting that these waters derive from a similar deep source. The concentration of chloride, which is relatively higher than $\mathrm{B}$ and $\mathrm{Li}$, indicates that the waters are from volcanic-magmatic processes. The processes involve dissolution of $\mathrm{HCl}$ and $\mathrm{H}_{2} \mathrm{~S}$ gasses (e.g. [4]). Chloride forms as $\mathrm{HCl}$ at high temperatures and changes to $\mathrm{Cl}$ ion at low temperatures. At near surface, $\mathrm{H}_{2} \mathrm{~S}$ will oxidize to $\mathrm{H}_{2} \mathrm{SO}_{4}$. Even though the thermal waters of Ciarinem are $\mathrm{SO}_{4}$ waters, the $\mathrm{pH}$ is neutral (between 7 and 8). It can be concluded that a conversion of acid fluids resulting from the oxidation of volcanic-magmatic fluids to neutral $\mathrm{pH}$ fluids has been ongoing for a very long time (e.g. [8]). It is also likely to be influenced by interaction with the surrounding rocks.

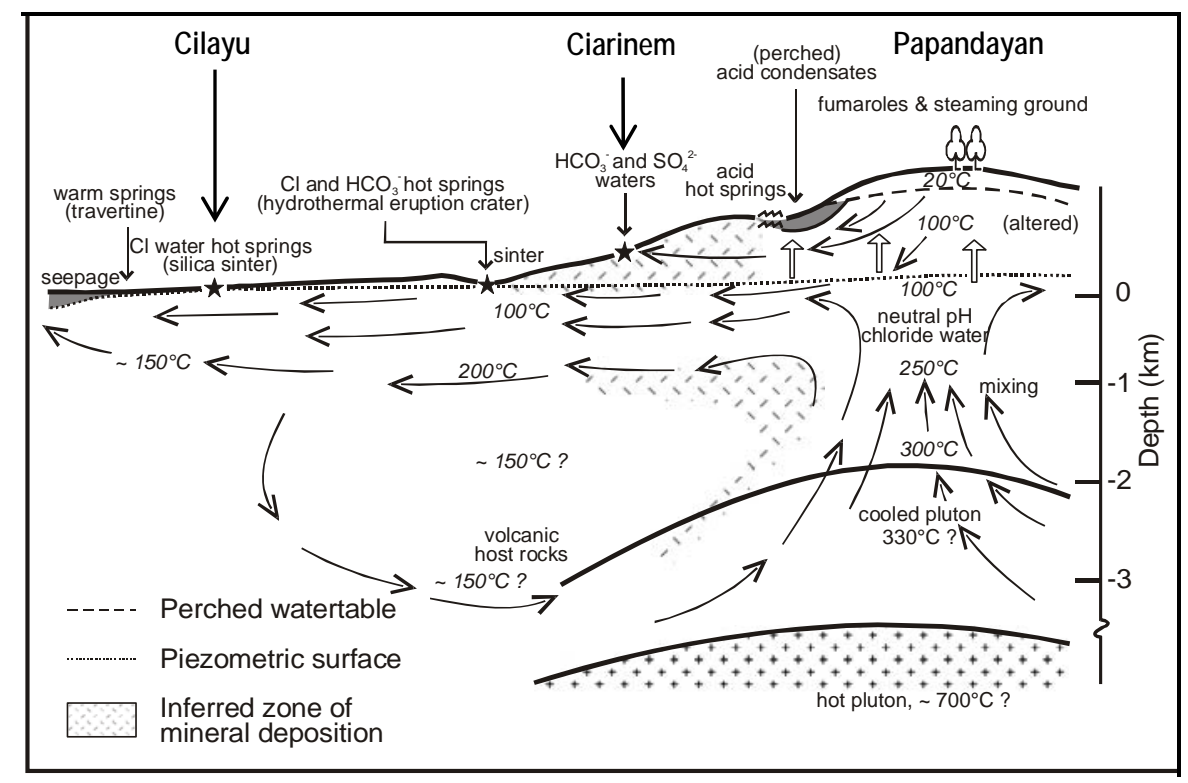

Figure 6 Schematic hydrologic model of subsurface flow within a liquid dominated, high-temperature system beneath a high standing volcanic complex (modified from [9]). The Ciarinem waters are chloride type thermal waters, whereas the Cilayu thermal waters are $\mathrm{SO}_{4}$-type. Both are outflows from the Papandayan geothermal system.

The chemical compositions of Ciarinem and Cilayu thermal waters suggest a volcanic-magmatic environment. Based on the hydrogeologic pattern, the Papandayan Volcano is likely to be the source of the geothermal system 
affecting outflows at Ciarinem and Cilayu. A general model (Figure 6) shows that chloride water (containing dissolved volcanic gasses) from the deep reservoir beneath Papandayan flows to the surface as upflow. The rising fluids can boil to produce steam and liquid. Boiling is usually followed by slight cooling.

Volatile components, such as $\mathrm{CO}_{2}$ and other volcanic gases, enter the steam phase and discharge as fumaroles and steaming grounds. The steam can also condense into groundwater and surface water to form steam heated $\mathrm{SO}_{4}$ and $\mathrm{HCO}_{3}$ waters. These waters flow and discharge as outflows in areas with lower elevation than the upflows of fumaroles and steaming ground. In the Papandayan geothermal system, this produces the hot springs in Ciarinem, Gunung Angsana. The neutral $\mathrm{pH}$ of $\mathrm{SO}_{4}$ waters at Ciarinem indicate that the outflows are far from the reservoir or upflows, hence the interaction between thermal water and surrounding rock has neutralized the thermal water.

The boiling chloride waters can then flow laterally below the groundwater level and discharge as outflows in Cilayu, Gunung Angsana, or mix with $\mathrm{SO}_{4}$ and $\mathrm{HCO}_{3}$ waters. The Cilayu thermal waters cool very slowly, hence the water is under saturated with respect to amorphous silica. As a result, there is no silica sinter deposit around the hot pool. However, colloidal silica, in association with organic matter and algae, occurs on the surface of the hot pools due to evaporation of the thermal waters.

Geothermometers of $\mathrm{K}-\mathrm{Na}$ and quartz with respect to maximum steam loss show that the reservoir of Ciarinem and Cilayu thermal waters has temperatures between $150^{\circ} \mathrm{C}$ and $200^{\circ} \mathrm{C}$. The prediction of natural heat loss of the surface manifestation at Ciarinem is 60 to $70 \mathrm{~kW}$ and that in Cilayu is about $1.6 \mathrm{~kW}$.

Even though the surface manifestations at Ciarinem and Cilayu relate to the geothermal system of Papandayan, there are at least two other possibilities. First, both surface expressions are outflows from the Patuha geothermal system. Or second, the two surface expressions are from different geothermal systems: the manifestation at Ciarinem relates to Papandayan and the other manifestation is an outflow from Patuha geothermal system. A tracer study using stable isotopes of $\delta^{18} \mathrm{O}$ and $\delta \mathrm{D}$ is recommended to further understand the origin of the Ciarinem and Cilayu thermal fluids.

\section{$5 \quad$ Conclusions}

The geothermal surface manifestations at Ciarinem, Gunung Angsana and Cilayu, Gunung Kendang, West Java are outflows of the Papandayan and/or Patuha Geothermal Systems. Even if Ciarinem and Cilayu thermal waters are 
from one system, the two waters have different characteristics: the thermal waters are of different types and chemical compositions, indicating that reservoir temperatures are slightly different.

The thermal water of Ciarinem is a sulfate $\left(\mathrm{SO}_{4}\right)$ type having an almost neutral $\mathrm{pH}$, whereas the thermal water of Cilayu is a chloride type having a neutral to slightly basis $\mathrm{pH}$. The sulfate thermal water is classified as immature water due to steam heating or mixing with groundwater. In contrast, the chloride thermal water of Cilayu is partially equilibrated water. Solute geothermometers indicate that the subsurface condition of Ciarinem is dominated by thermal fluids having temperatures of $110^{\circ}-150^{\circ} \mathrm{C}$. Reservoir fluids of Cilayu are hotter, i.e. between $180^{\circ}$ and $200^{\circ} \mathrm{C}$. Given that the thermal water of Ciarinem is not chloride water and cannot be used as solute geothermometer, the temperatures of the reservoir are likely ranging from $150^{\circ}$ to $200^{\circ} \mathrm{C}$.

The different characteristics and chemical compositions of the thermal springs at Ciarinem and Cilayu are likely due to the evolution of neutral $\mathrm{pH}$ and chloride rich reservoir fluids and volcanic gases from subsurface to surface condition. However, further study with for instance stable isotopes is required to confirm the reservoir condition and the hydrogeologic model relating to the geothermal surface expressions at Ciarinem and Cilayu, Gunung Angsana, Kendang, West Java, Indonesia.

\section{Acknowledgement}

This research was funded by ITB Research Grant No. 0076/K01.03/PL.1.5/VI/2005. Thanks to Andi Mardianza, Tri Yulinawati and Ari Surjoko at Geochemistry Laboratory for doing sample preparation. Chemical analysis by Mulyana Sukandar and Joko Subandrio, petrography photography by Andri Subandrio, and drafting by Adam Priohandono are highly appreciated.

\section{References}

[1] Ibrahim, R.F., Fauzi, A. \& Suryadarma, The progress of geothermal energy resources activities in Indonesia, Proceeding World Geothermal Congress, pp. 1-7, 2005.

[2] Alzwar, M., Akbar, N. \& Bachri, S., Geologi Lembar Garut dan Pameungpeuk, Jawa Barat, Pusat Penelitian dan Pengembangan Geologi, Direktorat Geologi dan Sumberdaya Mineral, Departemen Pertambangan dan Energi, Indonesia, 12 p, 1992.

[3] van Bemmelen, R.W., The Geology of Indonesia, Vol. 1A, The Hague, Government Printing Office, 732p, 1949. 
[4] Simmons, S.F., Stewart, M.K., Robinson, B.W. \& Glover, R.B., The Chemical and Isotopic Composition of Thermal Waters at Waimangu, New Zealand, Geothermics, vol.-, 539-554, 1994.

[5] Giggenbach, W.F., Geothermal Solute Equilibria. Derivation of Na-KMg-Ca Geoindicator, Geochimica et Cosmochimica Acta, 52, 2749-2765, 1988.

[6] Fournier, R.O., The Behaviour of Silica in Hydrothermal Solutions. In: Berger, B.R. and Bethke, P.M. (eds) Geology and Geochemistry of Epithermal Systems, Reviews in Economic Geology, 2, Society of Economic Geologist, 45-61, 1985.

[7] Koesmono, M., Kusbama \& Suwarna, N., Peta Geologi Lembar Sindangbarang dan Bandarbaru, Jawa, Pusat Penelitian dan Pengembangan Geologi, Direktorat Geologi dan Sumberdaya Mineral, Departemen Pertambangan dan Energi, Indonesia, 1996.

[8] Reyes, A.G., Giggenbach, W.F., Saleras, J.R.M., Salonga, N.D. \& Vergara, M.C., Petrology and Geochemistry of Alto Peak, A VaporCored Hydrothermal System, Leyte Province, Philippines, Geothermics, 22(5/6), 479-519, 1993.

[9] Hochstein, M.P. \& Browne, P.R.L., Surface Manifestation of Geothermal Systems with Volcanic Heat Sources, in Encyclopedia of Volcanoes, H. Sigurdsson, B.F. Houghton, S.R. McNutt, H. Rymer and J. Stix (eds.), Academic Press, pp. 835-855, 2000. 